\title{
Új antidiabetikum-csoportok cardiovascularis biztonságossága 2-es típusú diabetesben
}

\author{
Winkler Gábor dr. ${ }^{(1,2)}$
}

\section{Osszzefoglalắs}

A hatékony glykaemiás kontroll mellett a 2-es tipusú cukorbetegség antidiabetikus kezelésének mind hangsúlyosabb szempontja a cardiovascularis biztonság. A közlemény az alacsony hypoglykaemia-kockázatú újabb vércukorcsökkentö csoportokkal kapcsolatos cardiovascularis végpontú prospektiv, randomizált, párhuzamos csoportú vizsgálatok föbb jellemzöit tekinti àt. A vizsgált készitmény a súlyos keringési események összetett végpontja tekintetében valamennyi vizsgálatban - az antidiabetikus kezelést placebóval kiegészitö - kontroll ágon észlelttel összevethetönek (non-inferior), néhány származék (lira-, semaglutid, empa-, canagliflozin) esetében kedvezöbbnek (superior) bizonyult. A még folyamatban lévö, illetve már lezárult, de közzé még nem tett tanulmányok adatai tovább bövithetik ismereteinket és segithetik az antidiabetikus kezelés biztonságosságát.

Kulcsszavak: cardiovascularis biztonság, DPP-4-gátlók, GLP-1-receptor-agonisták, SGLT-2-gátlók

\section{Cardiovascular safety of newer antidiabetic compounds in type 2 diabetes}

Summary: Cardiovascular safety is a key issue of the antidiabetic therapy in type 2 diabetes. The article overviews the most important data of prospective randomized studies with prespecified cardiovascular endpoints of newer antidiabetic groups with low hypoglycemia risk. Every studied compound proved to be at least non-inferior concerning the composit endpoints of the major adverse cardiovascular events with those of the control arms, applying placebo to the basic antidiabetic therapy, some of them - lira-, semaglutide, empa-, canagliflozin - showed also superiority. Studies beeing in process, or already completed but at present with not published results may further improve our knowledge and help the safety of everydays practice.

Kulcsszavak: cardiovascular safety, DPP-4 inhibitors, GLP-1-receptor-agonists, SGLT-2 inhibitors

Rövidítések:

AACE: Amerikai Klinikai Endokrinológiai Társaság (American Association of Clinical Endocrinologists); ACE: Amerikai Endokrinológiai Kollégium (American College of Endocrinology); 95\% Cl: 95\%-os megbízhatósági tartomány (confidence interval); $\mathbf{C r C l}$ : creatinin clearence; e: becsült (estimated); ECVD: igazolt keringési betegség (established cardiovascular disease); HR: esélyhányados (hazard ratio); IA: instabil angina; MACE: súlyos nem kívánatos keringési esemény (major adverse cardiovascular event); MRF: többszörös kockázati tényező (multiple risk factor); RA: receptoragonista

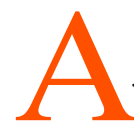

hatékony glykaemiás kontroll mellett napjaink antidiabetikus kezelésének kiemelt szempontja a cardiovascularis biztonság, ennek részeként az alacsony hypoglykaemia-kockázat és a testsúly előnyös - legalább testsúlysemleges, de inkább a súlycsökkenést elősegítő - hatás. ${ }^{1,2,3}$ A cardiovascularis veszélyeztetettség kérdése különösen az addig ígéretes terápiás lehetőségként számon tartott és széleskörüen alkalmazott rosiglitazonnal kapcsolatos metaanalízis várakozással 
ellentétes eredményének közzétételével került az érdeklődés előterébe. ${ }^{4}$ Jól ismert, hogy az adatok megismerését követően az amerikai Élelmiszer- és Gyógyszerügyi Hivatal (FDA) minden, a 2-es típusú diabetes (T2DM) kezelésére szánt, törzskönyvezésre benyújtott új antidiabetikum kapcsán kötelezővé tette a cardiovascularis biztonság vizsgálatát. ${ }^{5}$

A jelen közlemény az újabb antidiabetikum-csoportokkal - dipeptidilpeptidáz (DPP)-4-gátók, glukagonszerű peptid (GLP)-1-receptor-agonisták (RA-k), nátrium-glukóz kotranszporter (SGLT)-2gátlók - kapcsolatos, eddig ismertté vált cardiovascularis végpontú vizsgálatokat tekinti át, kiemelten elemezve az utóbbi csoport cardiovascularis biztonságára vonatkozó adatokat. ${ }^{3,6} \mathrm{~A}$ vizsgálatok egy része renalis végpontokra is kitér. Munkánk ezeket, valamint a bázisinzulinokkal folytatott cardiovascularis végpontú tanulmányokat nem érinti.

Az áttekintett vizsgálatok mindegyike randomizált, kontrollált, prospektív, kettős vak, párhuzamos csoportú, multinacionális, multicentrikus szervezésủ volt. A már befejezett vizsgálatok kontroll ágán az antidiabetikus terápia kiegészítéseként placebo szerepelt. Többségük fázis III stádiumú volt, a CANVAS Program (ld. később) részben postmarketing (fázis IV) jelleggel zajlott. A vizsgálatokba részben keringési eseményeken már átesett, részben azoktól mentes, de keringési kockázati tényezőkkel rendelkező személyeket vontak be ez utóbbiak bevonási életkorát a másik csoportba kerülőkénél magasabban határozták meg - és előre meghatározott keringési események gyakoriságát elemezték. A követési idő tartamát a statisztikai értékeléshez szükséges eseménygyakoriság elérése befolyásolta (eseményvezérelt tanulmányok). Minden tanulmány előre meghatározott elsődleges és másodlagos végpontokat is elemzett, amelyek részben eltértek egymástól. Az elsődleges végpontok egyike minden esetben ún. összetett (kompozit) végpont volt, amely súlyos keringési események - cardiovascularis eredetű halálozás, nem-halálos infarktus, nem-fatális stroke - együttes előfordulását vizsgálta (3 pontos súlyos cardiovascularis esemény [MACE]). Négypontos MACE értékelésekor az instabil angina miatt szükségessé váló kórházi beutalásokat is értékelték. A vizsgált készítmény placebóhoz viszonyított non-inferioritásának, azaz az elemzett esemény tekintetében összevethető voltának az volt a feltétele, hogy az aktív ágon talált esélyhányados (HR) 95\%-os megbízhatósági tartományának (95\% CI) felső határa 1,3-nál alacsonyabb legyen. Minden készítmény esetében a másodlagos végpontok között elemezték a szívelégtelenség miatt szükségessé váló kórházi felvételt is. ${ }^{3,6}$
DPP-4-gátlók

Az inkretinek lebontását is végző DPP-4 enzim szelektív, reverzibilis gátlása az inzulinelválasztást és a glukagon release-t vércukorfüggő módon gátolja. E hatásmechanizmusból adódóan a DPP-4-gátlók adását kísérő hypoglykaemia-kockázat igen alacsony. Alkalmazásukkor néhány Hgmm-rel csökkenhet a vérnyomás, a testsúly azonban érdemben nem változik. Mellékhatásprofiljuk kedvező. A hazai irányelv metforminintolerancia vagy -ellenjavallat esetén adásukat szakmai megfontolások alapján az első helyen ajánlja. ${ }^{7}$

Eddig három képviselőjük cardiovascularis biztonságot elemző vizsgálata fejeződött be, ${ }^{3,6,8}$ a saxagliptinnel folytatott SAVOR-TIMI $53,{ }^{9}$ az alogliptinnel végzett EXAMINE $^{10}$ és a sitagliptin adását követő TECOS tanulmány. ${ }^{11} \mathrm{~A}$ betegbevonási kritériumokat tekintve mindhárom lényegében szekunder prevenciós vizsgálatként értékelhető, mivel feltételként szerepelt korábbi cardiovascularis betegség, illetve többszörös kockázati tényező fennállása. ${ }^{3}$ Cardiovascularis előny egyik tanulmányban sem igazolódott, a vizsgált készítmények a placebo ágon adagolttal a 3 pontos MACE tekintetében egyenértékűnek (non-inferior) bizonyultak. A SAVOR-TIMI 53 ugyanakkor a saxagliptin ágon a szívelégtelenség miatt szükségessé váló kórházi beutalások számának fokozódását igazolta (HR 1,27 [95\% CI 1,07-1,51], p=0,007). Hasonló trend mutatkozott az EXAMINE vizsgálatban is (HR 1,19 [95\% CI 0,90-1,58], p=0,220). Két vizsgálat, az egyaránt linagliptinnel indított CAROLINA és a CARMELINA még folyamatban van. A heti egyszer adagolt omarigliptinnel kezdett OMNEON vizsgálatot a szponzor átlagosan 96 hetes követést követően leállította. ${ }^{3}$

\section{GLP-1-RA-k}

A GLP-1-RA-k inzulinelválasztást serkentő hatása ugyancsak vércukorfüggő - alacsony hypoglykaemia-kockázattal -, vérnyomást mérséklő és a vérzsírértékeket kedvezően befolyásoló természetük mellett további előnyként értékelhető súlycsökkenést elősegítő tulajdonságuk. A gyomorürülést hatástartamuktól függően befolyásolják. Étvágycsökkentő természetük molekulaméretük függvényében változik, az adásukat kísérő súlyleadás azonban megfigyelések szerint nemcsak a csökkent étvágy és energiafelvétel következménye. 
Adásuk kezdeti szakaszában émelygés, hányások fordulhatnak elő, kis kezdőadag alkalmazásával azonban ezek elkerülhetők, vagy legfeljebb átmenetiek. ${ }^{12}$ Az amerikai endokrinológiai társaságok (AACE, ACE) közös irányelve metforminintolerancia vagy -ellenjavallat esetén - testsúlyt csökkentő tulajdonságukat szem előtt tartva- első antidiabetikumként GLP-1-RA vagy - a lejjebb ismertetendő SGLT-2-gátlók választását támogatja.

Cardiovascularis biztonságuk felmérésére a csoport képviselőivel eddig nyolc prospektív vizsgálatot indítottak, közülük négy, a lixisenatiddal folytatott ELIXA,${ }^{13}$ a liraglutid hatását elemző LEADER,${ }^{14}$ a parenteralisan adagolandó semaglutiddal indított SUSTAIN-6, ${ }^{15}$ valamint a heti egyszer adott exenatiddal végzett EXSCEL tanulmány ${ }^{16}$ eredményei kerültek közlésre. ${ }^{3}$

A rövid hatású exenatid subcutan implantált, ozmotikus pumpaként működő változatával (ITCA 650) indított fázis III stádiumú FREEDOM-CVO vizsgálat befejeződött, de részletes eredményeit eddig nem ismertették. A forgalmazó sajtóközleménye a készítmény cardiovascularis biztonságosságáról számolt be. ${ }^{3}$ A dulaglutiddal indított REWIND study, az albiglutiddal 2015-ben kezdett vizsgálat, valamint az orális semaglutiddal indított PIONEER 6 tanulmány jelenleg is zajlik, befejeződésük a következő években várható. ${ }^{3}$

Az ELIXA vizsgálatba akut coronariaeseményt szenvedett T2DM-es személyeket vontak be, a másik három tanulmányban vegyesen, cardiovascularis és/vagy vesebetegségen korábban átesett, vagy azoktól mentes személyek szerepeltek. A LEADER és a SUSTAIN vizsgálatban ez utóbbi alcsoport esetében bevonási feltétel volt a $\geq 1$ keringési kockázati tényező megléte és a $\geq 60$ éves életkor, míg korábban kórismézett keringési vagy vesebetegség fennállásakor a bevonási életkor alacsonyabb ( $\geq 50$ év) volt.

A vizsgálatok közvetlen összevetése az eltérő anyagcsere-kritériumok, a diabetes ismert tartamában és a kísérő medikációban mutatkozó különbségek folytán alig lehetséges. Figyelemre méltó azonban, hogy a LEADER vizsgálatban a liraglutid ágon a kontroll ágon szereplőkéhez képest szignifikánsan alacsonyabb volt a 3 pontos összetett végpont (MACE), valamint a keringési eredetű halálozás esélyhányadosa $(0,87$ [95\% CI 0,78-0,97], illetve 0,78 [95\% CI 0,66-0,93]).
Az összetett végpont tekintetében hasonló „szuperioritást" igazolt a SUSTAIN-6 tanulmány is, igaz, ennek vizsgálata nem tartozott az előre meghatározott szempontok közé (HR 0,74 [95\% CI $0,58-0,94])$.

A LEADER vizsgálatban kedvezóbb volt a nem-fatális infarktus és a stroke esélyhányadosa is, statisztikai erő azonban nem volt igazolható (az összes infarktus vonatkozásában azonban a csökkenés szignifikáns mértékű volt). A SUSTAIN-6 tanulmányban szignifikánsan csökkent a nemfatális stroke $(0,61$ [95\% CI 0,28-0,99], p=0,04), nem szignifikáns mértékben a nem-fatális infarktus esélyhányadosa is $(0,74$ [95\% CI 0,51-1,08], $\mathrm{p}=0,12)$.

Az eredmények ismeretében az FDA 2017 augusztusában törzskönyvbe emelte a liraglutid súlyos cardiovascularis események kockázatát csökkentő szerepét T2DM-es felnőtteken, igazolt keringési betegségek fennállásakor. ${ }^{3}$ A kedvező adatok eredményeként megtörtént a parenteralisan, heti egyszer adható semaglutid amerikai törzskönyvezése is. Az ELIXA és az EXSCEL vizsgálatban a keringési események tekintetében non-inferioritás volt igazolható, cardiovascularis elôny azonban nem volt megertősíthető. ${ }^{3,6,8}$

\section{SGLT-2-gátlók}

Az SGLT-2-gátlók vércukorcsökkentő hatása inzulintól független, a vese proximális tubulusaiban található kotranszporter szelektív, reverzibilis gátlásán és a glucosuria következményes fokozódásán alapul. A glukotoxicitás mérséklésével csökkentik a béta-sejtek terhelését, mérséklik a szérum inzulinszintjét. Adásukat a vérnyomás, a testsúly és a szérum húgysavszintjének csökkenése kíséri. Szedésük nem jár a nem kívánt vércukoresések kockázatával. Kísérletes és klinikai megfigyelések kardio- és renoprotektivitásukat igazolták. ${ }^{17}$

A cardiovascularis biztonságosság tekintetében ez idő szerint két képviselőjükkel indított tanulmány - az empagliflozinnal folytatott EMPA-REG OUTCOME $^{18}$ és a - nálunk is törzskönyvezett, de ez idő szerint nem forgalmazott - canagliflozinnal végzett CANVAS ${ }^{19}$ - eredményei ismeretesek. A dapagliflozin cardiovascularis végpontú vizsgálata, a DECLARE ${ }^{20}$ most zárult, eredményeinek közzététele a közeljövőben várható. Egy további 
származék, a 2017-ben törzskönyvezett ertugliflozin hasonló, ugyancsak placebo-kontrollos vizsgálata még zajlik.

Az EMPA-REG vizsgálat az elsődleges összetett végpont tekintetében igen kedvező, 14\%-os relatívkockázat-csökkenést igazolt a kontroll ágon észlelthez képest (HR 0,86 [95\% CI 0,74-0,99], $\mathrm{p}=0,04$ a szuperioritás vonatkozásában). Szignifikáns mértékben csökkent a keringési eredetű halálozás (HR 0,62 [95\% CI 0,49-0,77], p<0,01), az összmortalitás (HR 0,68 [95\% CI 0,57-0,82], $\mathrm{p}<0,001)$ és a szívelégtelenség miatt történő kórházi beutalás esélyhányadosa is (HR 0,65 [95\% CI $0,50-0,65], p<0,001)$. A haszon-kockázat előnyös alakulása, a keringési kimenetelt jelző mutatók igen kedvező változása alapján a készítmény európai törzskönyvébe is bekerültek a vizsgálati adatok. $^{3}$

A CANVAS vizsgálatot eredetileg is kétszakaszosra tervezték. Az első szakasz eredményeit bevonták a törzskönyvezéskor benyújtott metaanalízisbe, ám szúrópróbaszerű, csoportszintű ellenőrzésükkor - nem várt módon - a szérum LDL-koleszterin-tartalmának dózisfüggő emelkedését észlelték. A tanácsadó testület az FDA-vel egyeztetve az eredmények közzététele és az addigi keringési események értékelésből történő kivonása mellett döntött, egyidejűleg szigorították ( $\leq 1,8$-ról $\leq 1,3$-ra csökkentették) a non-inferioritás eredetileg definiált megbízhatósági tartományának felső határértékét. A második szakaszként kezdett CANVAS-R vizsgálat és a fentiek szerint folytatott korábbi szakasz eredményeit összesítve, CANVAS Program néven értékelték. ${ }^{3}$ Az így elemzett vizsgálatban a 3 pontos kompozit végpont (MACE) 14\%-os relatívkockázat-csökkenést igazolt a canagliflozin ágon (HR 0,86 [95\% CI $0,75-0,97, \mathrm{p}<0,001])$, a non-inferioritás előzetesen meghatározott $\leq 1,3$ értéke tehát teljesült. ${ }^{3,6}$ Az elemzés szignifikáns $(\mathrm{p}=0,02)$ mértékű kockázatcsökkenést igazolt a szuperioritás - azaz a kontroll ágon észleltnél kedvezőbb kimenetel

1. táblázat. Az SGLT-2-gátlókkal végzett cardiovascularis végpontú prospektív-randomizált vizsgálatok föbb ada$\operatorname{tai}^{3,6,18,19,20}$

\begin{tabular}{|c|c|c|c|}
\hline Vizsgálati jellemzők & DECLARE & CANVAS PROGRAM & EMPA-REG OUTCOME \\
\hline Bevontak száma & $17160^{* 1}$ & $\begin{array}{c}10142 \\
\text { CANVAS: 4330, CANV.-R: } 5812\end{array}$ & 7020 \\
\hline $\mathrm{HbA}_{1 \mathrm{c}}$ vesemúködés bevonáskor & $\begin{array}{c}\geq 6,5 \%-<12,0 \% \\
\mathrm{CrCl}^{* 2} \geq 60 \mathrm{ml} / \mathrm{min}\end{array}$ & $\begin{array}{c}\geq 7,0-\leq 10,5 \% \\
\mathrm{eGFRc}^{* 3}>30 \mathrm{ml} / \mathrm{min} / 1,73 \mathrm{~m}^{2}\end{array}$ & $\begin{array}{c}\geq 7,0-\leq 10,0 \% \\
\mathrm{eGFR}^{* 3}>30 \mathrm{ml} / \mathrm{min} / 1,73 \mathrm{~m}^{2}\end{array}$ \\
\hline Követés átlagos ideje & 4,5 év & $\begin{array}{c}\text { 2,4 év } \\
\text { CANVAS: 5,7, CANV.-R: 2,1 év }\end{array}$ & 3,1 év \\
\hline Betegösszetétel & $\begin{array}{l}\text { ECVD: } 40,6 \% \\
\text { MRF:* } *^{4} 59,4 \%\end{array}$ & 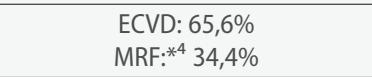 & ECVD: $100 \%$ \\
\hline Tervezett / elért eseményszám*5 & 1390 & CANVAS: 658, CANV.-R: 353 & 772 \\
\hline Randomizáció & $\begin{array}{c}\text { dapagliflozin } 10 \mathrm{mg} \text { vs. placebo } \\
1: 1\end{array}$ & $\begin{array}{c}\text { CANVAS: } \\
100 \mathrm{mg} / 300 \text { mg / placebo, 1:1:1 } \\
\text { CANV.-R: } \\
\text { 100-300 mg / placebo, 1:1 }\end{array}$ & $\begin{array}{c}\text { empagliflozin } 10 \mathrm{mg} / 25 \mathrm{mg} / \\
\text { placebo, } \\
1: 1: 1\end{array}$ \\
\hline Elsődleges végpont & $\begin{array}{l}\text { a } 3 \text { pontos MACE*6 első ese- } \\
\text { ményének bekövetkeztéig } \\
\text { eltelő idő; szívinfarktus; } \\
\text { ischaemiás stroke; CV halálozás } \\
\text { és a szívelégtelenség miatti } \\
\text { beutalások összetett végpontja }\end{array}$ & 3 pontos $\mathrm{MACE}^{* 6}$ & 3 pontos $\mathrm{MACE}^{* 6,7}$ \\
\hline Másodlagos végpont & összetett renalis végpontok & $\begin{array}{c}\text { halálozás bármely okból, renalis } \\
\text { végpontok }\end{array}$ & $\begin{array}{l}\text { MACE/IA miatti hospitalis, néma } \\
\text { MI és szívelégtelenség, összetett } \\
\text { végpontja, renalis végpontok }\end{array}$ \\
\hline
\end{tabular}

*1 30 beteg adatkezelési okokból kiesett, így a ténylegesen bevontak száma 17 130; *2 a Cockroft-Gault-formula alapján számolva; *3 a Modification of Diet in Renal Diseases (MDRD) képlet alapján számolva; ${ }^{*}$ egy vagy több keringési kockázati tényező fennállása; *5 a DECLARE vizsgálat esetében tervezett, a másik kettő esetében elért eseményszám; ${ }^{* 6}$ cardiovascularis halálozás, nem-fatális infarktus és nem-fatális ischaemiás stroke összetett végpontja; ${ }^{* 7}$ az empagliflozin két dózisa (10, illetve $25 \mathrm{mg}$ ) vonatkozásában összevontan értékelve 
- vonatkozásában is. Az összmortalitás tekintetében statisztikailag megerősíthető előny nem igazolódott (HR 0,90 [95\% CI 0,76-1,07], $\mathrm{p}=0,24$ ). A genitalis fertőzések valamivel magasabb előfordulása megfelelt az előzetes várakozásoknak, az alsó végtagi amputációk csaknem kétszeres gyakorisága (6,3 vs. 3,4 esemény/1000 betegév) és a csonttörések relatív kockázatának 26\%-os emelkedése (15,4 vs. 11,9 csonttörés/1000 betegév) azonban váratlan megfigyelés volt, okai minden tekintetben egyelőre nem tisztázottak. ${ }^{3,8}$

A dapagliflozin esetében ez idő szerint metaanalízisből, ${ }^{21}$ illetve ún. „való világ vizsgálatokból” (RWE) származó adatok (CVD REAL, ${ }^{22}$ CVD REAL Nordic ${ }^{23}$ ) ismertek a készítmény kedvező keringési hatásairól. Éppen ezért kíséri nagy várakozás az SGLT-2-származékokkal folytatott eddigi legnagyobb esetszámú (17130 fő!) és leghosszabb követési idejü (átlagosan 4,5 év) DECLARE (eredetileg DECLARE TIMI 58) vizsgálat eredményeinek nyilvánosságra hozatalát. E vizsgálat eredményeinek külön hangsúlyt adhat, hogy a fennálló cardiovascularis betegséggel bevontak aránya jóval alacsonyabb a másik két származékkal folytatott vizsgálatban szereplőkéhez képest (1. táblázat). Fontos további körülmény, hogy a 3 pontos MACE első eseményének bekövetkeztéig eltelő idő mellett elsődleges végpontként külön elemzi a napi klinikai gyakorlat tekintetében meghatározó jelentőségủ keringési halálozást, a szívinfarktus, valamint az ischaemiás stroke előfordulását, s elemzi a cardiovascularis halálozás és a szivelégtelenség miatt szükségessé váló hospitalizáció öszszetett végpontját is. E kérdések statisztikailag alátámasztott vizsgálata az eddigieknél pontosabb képet adhat a készítmény cardiovascularis kimenetelt érintő hatásáról.

\section{Az adatokból levonható következtetések}

Napjaink vércukorcsökkentő kezelésének kiemelt szempontja a cardiovascularis biztonság kérdése. ${ }^{1,2,3,6,7,24} \mathrm{Az}$ inzulinokkal (degludek, glargin) folytatot $^{3}$ - ehelyütt nem tárgyalt - , valamint a DPP-4-gátlókkal, a lixisenatiddal, illetve az exenatiddal indított vizsgálatok összetett végpont tekintetében a kontroll ágon észlelt eredményekkel összevethető (non-inferrior) voltának igazolódása a kezelőorvosok számára e tekintetben nagy biztonságot kínál.

Néhány vizsgálat még kedvezőbb („szuperior”) keringési kimenetelt meggyőzően bizonyító adatai kezelési stratégiánk újragondolását teszik már most is szükségessé, ami várhatóan a közeljövőben megújításra kerülő kezelési irányelvekben is tükröződni fog. E tekintetben további támpontot szolgáltathatnak a már lezárult - de eredményei tekintetében még nem ismert -, illetve a még folyamatban lévő tanulmányok. Adataik segíthetik a csoport- vagy egyedi hatás ma még nem minden tekintetben tisztázott kérdésének, továbbá annak megválaszolását, hogy az esetenként észlelt váratlan megfigyelések vizsgálattechnikai okok pl. a különböző vizsgálati populációk, beválasztási és kizárási kritériumok -, esetleg a hatásmechanizmus még pontosabban feltárandó részleteinek következményei. A ma ismert adatok alapján elsősorban a lira-, a semaglutid és az empagliflozin preferált választása támogatható, a DECLARE adatainak megismerésével azonban e sort bővítheti a dapagliflozin is. E vizsgálat a két betegcsoport, az igazolt keringési betegségben (ECVD) megbetegedettek, illetve az attól mentes, de keringési kockázati tényezők (MRF) tekintetében veszélyeztetettek tekintetében is szolgáltathat majd adatokat.

A jelen munkánknak nem feladata, hogy állást foglaljon a metformin intolerancia/ellenjavallat esetén elsőként választandó gyógyszercsoport vagy készítmény tekintetében, ugyanígy, hogy bármiféle preferenciát sugalljon a metformin melletti kombinációs kezelés megválasztásában. E kérdések mélyrehatóbb elemzést igényelnek, s az összes lehetséges szempont figyelembevételével lehet majd útmutatást adni. A bemutatott adatok ugyanakkor meggyőzően szemléltetik, hogy több gyógyszercsoport esetében van olyan készítmény - esetenként több is -, amelynek cardiovascularis előnyei bizonyítottak. A választást mindig az adott esetre vonatkozóan kell mérlegelni. 


\section{Irodalom}

1. American Diabetes Association: Cardiovascular disease and risk management - Standards of medical care in diabetes - 2018. Diabetes Care 2018, 41(Suppl. 1): S86-S104. doi:10.2337/dc18-5009

2. Garber AJ, Abrahamson MJ, Barzilay II, Blonde L, Bloomgarden ZT, Bush MA, et al: Consensus Statement by the American Association of Clinical Endocrinologists and American College of Endocrinology on the Comprehensive Type 2 Diabetes Management Algorhythm - 2018 exutive summary. Endocr Pract 2018; 24(1): 91-120. doi:10.4158/CS-2017-0153

3. Cefalu WT, Kaul S, Gerstein HC, Holman RR, Zinman B, Skyler IS, et al.: Cardiovascular outcome trials in type 2 diabetes: where do we go from here? Reflections from a Diabetes Care editors' expert forum. Diabetes Care 2018; 41(1): 14-31. doi:10.2337/dci17-0057

4. Nissen SE, Wolski K: Effect of rosiglitazone on the risk of myocardial infarction and death from cardiovascular causes. N Engl J Med 2007; 356(24): 2457-2471. doi:10.1056/NEJMoa072761

5. U.S. Food and Drug Administration: Guidance for industry: Diabetes mellitus - evaluating cardiovascular risk in new antidiabetic therapies for type 2 diabetes. U.S. FDA CDER, 2008. http://www.fda.gov/downloads/Drugs/Guid anceComplianceRegulatoryInformation/Guidances/ucm071627.pdf

6. Jermendy Gy: Kardiológiai vonatkozású diabetológiai újdonságok. Cardiologia Hungarica 2018; 48(2): 151-161.

7. Egészségügyi szakmai kollégium: A diabetes mellitus kórismézéséról, a cukorbetegek antihyperglykaemiás kezeléséról és gondozásáról felnöttkorban. Egészségügyi szakmai irányelv (szerk.: Jermendy Gy). Diabetol Hung 2017; 25(1): 3-83.

8. Schnell 0 , Rydén L, Standl E, Ceriello A and on behalf of the D\&CVD EASD Study Group: Updates on cardiovascular outcome trials in diabetes. Cardiovasc Diabetol 2017; 16: 128.

9. Scirica BM, Bhatt DL, Braunwald E, Steq PG, Davidson J, Hirshberg B, et al., SAVOR-TIMI 53 Steering Committee and Investigators: Saxagliptine and cardiovascular outcomes in patients with type 2 diabetes mellitus. N Engl I Med 2013; 369(14): 1317-1326. doi:10.1056/NEJMoa1307684

10. White WB, Cannon CP, Heller SR, Nissen SE, Bergenstal RM, Bakris GL, et al., EXAMINE Investigators: Alogliptin after acute coronary syndrome in patients with type 2 diabetes. N Engl J Med 2013; 369(14): 1327-1335. doi:10.1056/NEJMoa1305889

11. Green JB, Bethel MA, Armstrong PW, Buse JB, Engel SS, Garg J, et al., TECOS Study Group: Effect of sitagliptin on cardiovascular outcomes in type 2 diabetes. N Engl J Med 2015; 373(3): 232-242. doi:10.1056/NEJMoa1501352

12. Winkler G: A hosszú és rövid hatású GLP-1 receptor-agonisták áttekintése. A heti egyszer adagolt GLP-1 receptor-agonista dulaglutid (Trulicity ${ }^{\circ}$ ) helye a 2-es típusú diabetes kezelésében. Diabetol Hung 2016; 24(2): 99-116.

13. Pfeffer MA, Claggett B, Diaz R, Dickstein K, Gerstein HC, Køber LV, et al., ELIXA Investigators: Lixisenatide in patients with type 2 diabetes and acute coronary syndrome. N Engl J Med 2015; 373(23): 2247-2257. doi:10.1056/NEJMoa1509225

14. Marso SP, Daniels GH, Brown-Frandsen K, Kristensen P, Mann JF, Nauck MA, et al., LEADER Steering Committee, LEADER Trial Investigators: Liraglutide and cardiovascular outcomes in type 2 diabetes. N Engl J Med 2016; 375(4): 311-322. doi:10.1056/NEJMoa1603827

15. Marso SP, Bain SC, Consoli A, Eliaschewitz FG, Jódar E, Leiter LA, et al., SUSTAIN-6 Investigators: Semaglutide and cardiovascular outcomes in patients with type 2 diabetes. N Engl J Med 2016; 375(19): 1834-1844 doi:10.1056/NEJMoa1607141

16. Holman RR, Bethel MA, Mentz RL, Thompson VP, Lokhnygina Y, Buse JB, et al., EXSCEL Study Group: Effects of once weekly exenatide on cardiovascular outcomes in type 2 diabetes. N Engl I Med 2017; 377(13): 1228-1239. doi:10.1056/NEJMoa1612917
17. Winkler G: Az SGLT-2-gátlók („gliflozinok") kardiovaszkuláris biztonsága. Metabolizmus 2017; 15(4): 242-247.

18. Zinman B, Wanner C, Lachin JM, Fitchett D, Bluhmki E, Hantel S, et al., EMPA-REG OUTCOME Investigators: Empagliflozin, cardiovascular outcomes, and mortality in type 2 diabetes. N Engl J Med 2015; 373(22): 2117-2128. doi:10.1056/NEJMoa1504720

19. Neal B, Perkovic V, Mahaffey W, de Zeeuw D, Fulcher G, Erondu N, et al.: CANVAS Program Collaborative Group: Canagliflozin and cardiovascular and renal events in type 2 diabetes. N Engl J Med 2017; 377(7): 644-657. doi:10.1056/NEJMoa1611925

20. Wiviott SD, Raz I, Bonaca MP, Mosenzon 0, Kato ET, Cahn A, et al.: The design and rationale for the Dapagliflozin Effect on Cardiovascular Events (DECLARE)-TIMI 58 Trial. Amer Heart J 2018; 200(1): 83-89. doi:10.1016/j.ahj.2018.01.012

21. Sonesson C, Johansson PA, Johnson E, Gause-Nilsson I: Cardiovascular effects of dapagliflozin in patients with type 2 diabetes and different risk categories: a meta-analysis. Cardiovasc Diabetol 2016; 15:37, 1-12. doi:10.1186/s12933-016-0356-y

22. Kosiborod M, Cavender MA, Fu AZ, Wilding JP, Khunti K, Holl RW, et al: Lower risk of heart failure and death in patients initiated on sodium-glucose cotransporter-2 inhibitors vs. other glucose-lowering drugs. The CVD-REAL study (Comparative effectiveness of cardiovascular outcomes in new users of sodium-glucose cotransporter-2 inhibitors). Circulation 2017; 136(3): 249-259. doi:10.1161/CIRCULATIONAHA.117.029190

23. Persson F, Nyström T, Jørgensen ME, Carstensen B, Gulseth HL, Thuresson M, et al: Dapagliflozin compared to DPP-4 inhibitors is associated with lower risk of cardiovascular events and all-cause mortality in type 2 diabetic patients (CVD-REAL Nordic): a multinational observational study. Diabetes Obes Metab 2018; 20(2):344-351. doi:10.1111/dom.13077

24. Lipscombe L, Booth G, Butalia S, Dasgupta K, Eurich DT, Goldenberg R, et al.: Pharmacologic glycemic management of type 2 diabetes in adults. Diabetes Canada Clinical Practice Guidelines Expert Committee. Can J Diabetes 2018; 42(Suppl. 1): S88-S103. doi:10.1016/j.jjjd.2017.10.034

Közlésre érkezett: 2018 . augusztus 9.

Közlésre elfogadva: 2018 . augusztus 30.

\section{A szerzö levelezési címe:}

\section{Prof. Dr. Winkler Gábor}

Szent János Kórház, II. Belgyógyászat-Diabetológia

1025 Budapest, Diós árok 1-3.

E-mail: gabor.winkler@janoskorhaz.hu 